\title{
Aplikasi Pengelolaan Dana ZIS Pada Lembaga Zakat, Infaq, dan Shadaqah (Lagzis) Kota Malang
}

\author{
A. Muhtadi Ridwan
}

\begin{abstract}
This Research on the application of management on zakat, infaq and shadaqah (zis) aims to understand deeply the model and mechanism of the management of zakat finance in terms of its collection, distribution and application. This study specifically looks upon the system of plaming, organizing, actuating, and controlling focused on the zakat, infaq, and shadaqah institution in Malang.

This study uses a qualitative approach by using a case study method, a study which puts the emphasis on the richness and depth of the object being studied. This study is conducted in LAGZIS of Malang, an institution founded in 1999 and considered representative, credible, and professional in managing the zis finance. The data of the research were collected through documentation, participatory observation, deep interview with the informants so as the researcher could get the information about the growth, progress and even future programs of development.

From the result of data analysis, it is found out that as an institution, LAGZIS in Malang has met the formal prerequisite as an amil zakat, infaq and shadaqah institution with its legal authority. However, this institution has not been accredited by the government as stated in the Constitution No. 38, 1999 on the zakat management.

Nevertheles, this institution represents itself as a modern and professional using the trustworthy principles (amanah) with Islamic missions, due to the fact that the working mechanism is based on the four aspects of management; planning, organizing, actuating, and controlling while paying much attention to the values related to the zakat, infaq, and sahdaqah and also the relevant lows such as the Constitution No. 38, 1999 on the zakat management with its related rules.

Based on the four aspects of management mentioned above (planning, organizing, actuating, and controlling), the management of the LAGZIS Malang is relatively wellorganized.
\end{abstract}

Ulul Albab, Vol. 4 No. 1, 2002 


\section{Pendahuluan}

\section{A. Latar belakang Masalah}

Sebagai salah satu pilar Islam, zakat adalah fardlu 'ain dan kewajiban ta' abbudi. Ia juga merupakan ibadah maliyah ijtima'iyah (ibadah yang berkaitan dengan ekonomi dan kemasyarakatan) yang mempunyai status dan fungsi penting dalam syariat Islam¹. Bahkan al-Qur'an menjadikan zakat dan shalat sebagai lambang dari keseluruhan ajaran Islam. ${ }^{2}$

Zakat merupakan kewajiban keagamaan dan bersifat ibadah kemasyarakatan yang pengembangannya dapat dipikirkan dengan jalan ijtihad. Zakat dan berbagai bentuk ibadah sedekah lainnya memiliki posisi potensial sebagai sumber pembelanjaan dalam masyarakat muslim, juga sebagai sumber daya untuk mengatasi berbagai macam social cost yang diakibatkan dari hubungan antar manusia. Zakat, disamping berposisi fardlu 'ain dan sedekah lainnya yang berposisi sunnah, juga merupakan potensi ekonomik yang mampu atau setidak-tidaknya dapat memberikan konstribusi dalam rangka membangun pertumbuhan ekonomi sekaligus pemerataan incomeeconomic growth with equity, apabila dikelola secara optimal dan profesional.

Argumentasi berdasarkan naqli, al-Qur'an dan al-Hadis banyak memberikan penjelasan tentang latar belakang disyariatkannya zakat dalam Islam. Persoalan selanjutnya adalah bagaimana mewujudkan pengelolaan zakat agar tercapai secara optimal dan tepat, yakni tepat nilai, tepat sasaran, tepat guna, tepat waktu, dan tepat tempat.

Motivasi keagamaan, niat baik dan ikhlas dalam rangka ibadah kepada Allah SWT adalah dasar pendekatan untuk mengurangi kesenjangan antara si kaya dan si miskin untuk mewujudkan keadilan dalam kemakmuran dan kemakmuran dalam keadilan. Di samping itu, secara teknis ada dua pendekatan yang dapat dipertimbangkan, yakni :

1. Pendekatan parsial, yaitu pertolongan terhadap si miskin yang dilaksanakan secara langsung dan bersifat insidental untuk mengatasi masalah kemiskinan yang mendesak dan gawat.

2. Pendekatan struktural, yaitu lebih mengutamakan pemberian pertolongan secara kontinu yang bertujuan agar si miskin dapat mengatasi masalah 
kemiskinannya, dan bahkan diharapkan nantinya mereka menjadi muzakki (wajib zakat), tidak lagi berstatus sebagai mustahiq (penerima zakat). Dengan pendekatan ini harus lebih dahulu mencari dan mengidentifikasi sebab-sebab adanya kelemahan atau kemiskinan dan berusaha memecahkannya. Dengan pendekatan struktural ini diharapkan dapat memecahkan masalah kemiskinan tidak secara insidental, tetapi justru mengubah atau memperbaiki penyebab yang paling dasar dari kemiskinan, kebodohan, kemalasan, kelemahan, keterbelakangan, ketertinggalan dan lain sebagainya. Untuk mewujudkan pendekatan itu perlu membangun kelembagaan manajemen zakat yang profesional.

Menurut data yang diperoleh, justru upaya tersebut sudah dilakukan sebelum Indonesia merdeka, yaitu pada zaman Hindia Belanda dan pendudukan Jepang. ${ }^{3}$ Kemudian setelah Indonesia merdeka, secara berangsur-angsur pemerintah memberikan perhatian terhadap pelaksanaan zakat, dengan bukti telah diterbitkannya berbagai macam dokumen resmi, mulai dalam bentuk surat edaran yang dikeluarkan Menteri Agama atau Menteri Dalam Negeri, Surat Keputusan bersama (Menteri Agama dan Menteri Dalam Negeri), Keppres, sampai terakhir lahir Undang-Undang Nomor 38 Tahun 1999 Tentang Pengelolaan Zakat dan Peraturan Perundangan lainnya yang berkaitan dengan pengelolaan zakat.

Dengan demikian, baik secara historis, maupun yuridis formal betapa sangat besar dan jelas jaminan terhadap pengelolaan zakat, termasuk juga dana infaq, shadaqah dan dana lainnya yang menjadi wilayah pengelolaan lembaga amil zakat sebagaimana diatur menurut undang-undang.

Disamping itu, juga sudah banyak usaha pengelolaan zakat secara melembaga dengan beraneka bentuk dan namanya, namun menurut pengamatan sementara masih belum tertangani secara optimal, sehingga belum memenuhi harapan, dan tidak menutup kemungkinan memunculkan persoalan-persoalan hukum (syar'i) yang segera mendapat perhatian. Pengamatan seperti itu juga muncul di kalangan cendikiawan muslim dan ulama, sebagaimana Yafie memprediksi bahwa potensi zakat mengandung arti cukup besar untuk membangun secara keseluruhan, khususnya dalam upaya pengentasan kemiskinan jika potensi ini sunguh-sungguh digali, dikembangkan dan ditata dengan sebaik-baiknya. Namun potensi tersebut belum mencapai taraf optimal dalam hal penggalian, pengembangan, penataan dan pemanfaatannya ${ }^{4}$

Ulul Albab, Vol. 4 No. 1, 2002 
Mahfudh ${ }^{5}$ menyatakan bahwa pengelolaan zakat di masyarakat belum sesuai dengan harapan. Untuk itu perlu bimbingan dari segi syari'ah, metode yang tepat dan mantap. Dari sisi muzakki misalnya, masih melaksanakannya secara terpencar. Pembagiannyapun masih jauh dari memuaskan. Untuk itu, perlu penataan lembaga zakat itu sendiri. Penataannya tidak terbatas dengan pembentukan panitia, namun lebih dari itu, hendaknya juga menyangkut aspek manajemen modern yang dapat diandalkan agar zakat menjadi kekuatan yang bermakna. Penataan itu menyangkut aspek pendataan, pengumpulan, penyimpanan, pembagian dan sumber daya manusianya. Lebih dari itu, aspek yang berkaitan dengan syari'ah tidak bisa dilupakan. Ini berarti memerlukan organisasi yang kuat dan rapi.

Demikian juga yang pernah dinyatakan oleh Basyir bahwa usaha pengelolaan zakat, walaupun sudah dilaksanakan namun yang segera mendapat perhatian adalah bagaimana intensifikasi pengumpulan dan pendayagunaannya, disamping pemasyarakatan rasa wajibnya. ${ }^{6}$

Menurut prakiraan, daerah Kota Malang memiliki potensi zakat yang tidak kecil. Prakiraan ini berdasarkan perhitungan, bahwa jumlah penduduk Kota Malang yang beragama Islam (berdasarkan data keagamaan tahun 2001 sebesar 673.672 jiwa atau kurang lebih 168.841 keluarga $(1: 4),{ }^{7}$ akan diperoleh sedikitnya dana sebesar Rp. 6.302.888.250,- (Enam milyard, tiga ratus dua juta, delapan ratus delapan puluh delapan ribu dua ratus lima puluh rupiah).

Bertolak dari prediksi bahwa masyarakat yang menunaikan wajib zakatnya minimal $10 \%$, maka diketemukan sedikitnya 16.841 wajib zakat. Jika prediksi ini tidak meleset, dan diumpamakan masing-masing wajib zakat memenuhi kewajibannya pada batas nishab (jumlah minimal harta yang wajib dikeluarkan zakatnya) terendah dengan perhitungan zakat yang dibayarkan 2,5\%, maka di Kota Malang sedikitnya akan terkumpul harta zakat sebesar Rp. 3.310.309.062,50,(tiga milyard, tiga ratus sepuluh juta, tiga ratus sembilan ribu, enam puluh dua setengah rupiah) untuk tahun $2001 .^{8}$ Kemudian untuk zakat fitrah, karena merupakan zakat perorangan yang diprakirakan tingkat kesadaran masyarakat lebih besar daripada zakat mal, maka dapat diperkirakan ada sekitar $60 \%$ wajib zakat memenuhi kewajibannya. Maka hasilnya akan terkumpul sekitar $1.010 .508 \mathrm{~kg}$ beras atau 1.010 ton 5 kwintal, dan jika diuangkan maka akan terkumpul uang sebesar Rp. 3.031.524.000,- (Tiga milyard, tiga puluh satu juta, lima ratus dua puluh empat ribu rupiah. ${ }^{9}$ 
Jadi prakiraan hasil zakat untuk dua jenis zakat tersebut menurut data penduduk Kota Malang tahun 2001 sebesar Rp. 3.271.364.250,- + Rp. $3.031 .524 .000,-=$ Rp. 6.302.888.250,- (Enam milyard, tiga ratus dua juta, delapan ratus delapan puluh delapan ribu dua ratus lima puluh rupiah).

Potensi besar seperti itu, tampaknya belum bisa ditangkap secara baik oleh lembaga-lembaga sosial-keagamaan khususnya yang bergerak dalam bidang pengelolaan Zakat dimana selama ini pengelolaan zakat masih dilakukan secara tradisional baik dalam pengumpulan maupun pendistribusiannya. Padahal jika potensi umat itu dapat dikelola dengan baik tentu akan sangat membantu dalam pembangunan sosial, khususnya di bidang ekonomi umat Islam.

Karena belum ada lembaga yang profesional seperti itu, maka berdasarkan hasil pengamatan sepintas, terkesan banyak masyarakat Islam (wajib zakat) kota Malang masih ada yang enggan untuk berpartisipasi di lembaga-lembaga pengelolaan zakat yang ada, sehingga belum memenuhi sasaran yang diharapkan. Ada semacam kekhawatiran di kalangan wajib zakat, kalau-kalau zakat itu tidak akan sampai ke tangan penerima zakat yang sebenarnya berhak.

Kenyataan itulah yang melatarbelakangi berdirinya Lembaga Zakat Infak dan Sadaqah (LAGZIS) kota Malang. Lembaga ini mencoba untuk tampil menjadi salah satu lembaga ZIS yang profesional dan amanah dalam mengelola zakat berdasarkan teori-teori manajemen terapan yang diharapkan dapat mengefektifkan dana umat Islam. Sehingga lembaga ini selalu berusaha menggunakan mekanisme kerja yang ditata secara rapi dan modern.

Itulah sebabnya, peneliti sangat menaruh perhatian untuk melihat secara dekat kinerja LAGZIS kota Malang dalam melaksanakan program pengelolaam dana zis. dengan menitikberatkan perhatian pada aspek menajerial pengelolaan zis. Fokus perhatian dalam penelitian ini akan dikhususkan pada persoalan bagaimana pengelolaan zakat oleh LAGZIS kota Malang sebagai suatu lembaga penghimpun maupun penyalur dana zis. kepada masyarakat (umat).

\section{B. Rumusan Masalah}

Berdasarkan paparan latar belakang masalah di atas, maka ada tiga persoalan yang akan dijawab dalam penelitian ini. Pertama, bagaimana pola perencanaan 
dalam pengelolaan dana zis yang dilakukan oleh LAGZIS kota Malang ?. Kedua, bagaimana mekanisme pengorganisasiannya ?. Ketiga, bagaimana pola pelaksanaan dan pengawasannya?

Ketiga persoalan ini penting untuk dijawab untuk mengetahui sejauhmana sistem dan mekanisme kerja yang diterapkan oleh LAGZIS kota Malang dalam mengelola dana zis.

\section{Tujuan dan Kegunaan Penelitian}

Penelitian ini secara umum ingin mengkaji secara mendalam model dan mekanisme pengelolaan dana zis yang diaplikasikan oleh LAGZIS kota Malang, baik penghimpunan, pendistribusian, dan pendayagunaannya. Kajian ini secara khusus melihat bagaimana sistem perencanaan, sistem pengorganisasian, sistem pelaksanaan, dan sistem pengawasannya.

Hasil penelitian ini diharapkan dapat memberikan informasi ilmiyah tentang gambaran mengenai model dan mekanisme pengelolaan dana zis yang tentunya akan besar manfaatnya, baik untuk langkah penelitian selanjutnya, maupun untuk menyusun langkah kebijakan dalam usaha menggali dan mendayagunakan potensi dana zis di wilayah kota Malang.

\section{Landasan Teori}

Sebagaimana disebutkan di atas bahwa fokus kajian dalam penelitian ini adalah tentang bagaimana pengelolaan dana Zakat Infak dan Sadaqah (zis) yang diaplikasikan oleh LAGZIS kota Malang.

Pengelolaan yang dimaksud di sini adalah meliputi kegiatan perencanaan, pengorganisasian, pelaksanaan, dan sekaligus pengawasannya. Terutama terhadap bagaimana kinerja pengumpulan dan pendistribusian serta pendayagunaan dana zis sesuai dengan Undang-Undang Republik Indonesia Nomor 38 Tahun 1999 Tentang Pengelolaan Zakat, bab I Ketentuan Umum Pasal 1 ayat (1). Karena Pengelolaan adalah masalah manajemen, maka landasan teori sebagai grand teori dalam tesis ini adalah teori dasar-dasar manajemen. 
Dasar-dasar manajemen tersebut mengacu pada teori James L. Gibson (Gibson), James H. Donnelly, JR. (Donnelly), dan John M. Ivancevich (Ivancevich) dalam Fundamentals of Management yang dialih bahasakan oleh Zuhad Ichyaudin dengan judul Manajemen, edisi kesembilan jilid 1 (1996) dan jilid 2 (1997) dialih bahasakan oleh Sularso Tjiptowardoyo dan Imam Nurmawan. Untuk mempertajam analisis penulis juga mengacu teori-teori managemen yang lain sebagai perbandingan, seperti yang ditulis oleh Mamduh (1997) dalam bukunya Manajemen. Teori ini dijadikan sebagai rujukan, karena teori-teori manajamen tersebut, menurut penulis cukup representatif dan sangat aplikatif, terutama dalam mengelola suatu lembaga semacam LAGZIS kota Malang, yang bergerak dalam bidang pengelolaan dana zis.

Teori-teori tersebut dapat dikemukakan sebagai berikut :

Suatu organisasi, lembaga, atau badan yang profesional adalah organisasi, lembaga, atau badan yang di dalamnya terdapat kegiatan yang dilakukan berdasarkan proses manajemen atau kegiatan yang dilakukan secara sistematis. Kegiatan tersebut berupa empat kerangka dasar manajemen, yaitu perencanaan, pengorganisasian, pengarahan, dan pengendalian atau pengawasan. ${ }^{10}$ Urutan penyebutan empat kerangka dasar manajemen tersebut menunjukkan urutan kegiatan secara teoritis, dimulai dari perencanaan, kemudian diakhiri oleh pengendalian, yang kemudian berputar lagi kembali ke perencanaan.

Sementara buku lain ada yang menggunakan tiga kerangka dasar; Perencanaan, Pengorganisasian, dan Pengendalian atau Perencanaan, Pelaksanaan, dan Pengendalian, ada juga yang menggunakan lima kerangka dasar; Perencanaan, Pengorganisasian, staffing, Leading, dan Pengendalian. Perbedaan di atas secara subtantif sebenarnya semata-mata karena tergantung selera masing-masing penulis. Artinya tidak mengurangi atau menafikan subtansi dari kerangka dasar manajemen.

Seperti Gibson, et.al ${ }^{11}$ menggunakan tiga kerangka dasar; Perencanaan, Pengorganisasian, dan Pengendalian, karena Pelaksanaan, Pengarahan, Staffing, dan Leading masuk pada kerangka dasar Pengorganisasian, dan seperti juga Mamduh ${ }^{12}$ menggunakan empat kerangka dasar; Perencanaan, Pengorganisasian, Pengarahan, dan Pengendalian, yakni Pengorganisasian dan Pengarahan disebut sebagai kerangka dasar tersendiri, karena Pengorganisasian termasuk di dalamnya Staffing dan Leading, sedangkan Pengarahan termasuk di dalamnya Pelaksanaan. 
Untuk menyesuaikan obyek penelitian dalam tesis ini, penulis berusaha mengkombinasikan berbagai bentuk penggunaan atau pengelompokan kerangka manajemen di atas, sehingga kerangka dasar manajemen yang penulis pakai adalah Perencanaan, Pengorganisasian, Pelaksanaan, dan Pengendalian

Jika dihubungkan dengan kegiatan organisasi pengelola zakat sebagaimana diatur dalam pasal 1 ayat (1) UU nomor 38 tahun 1999, bahwa pengelolaan zakat adalah kegiatan perencanaan, pengorganisasian, pelaksanaan, dan pengawasan terhadap pengumpulan dan pendistribusian serta pendayagunaan zakat, maka pemakaian teori di atas sebagai grand teori adalah sangat relevan.

Pemakaian UU RI nomor 38 tahun 1999, penjelasan UU RI. nomor 38 tahun 1999, dan KMA. RI tentang Pelaksanaan UU RI nomor 38 tahun 1999 di atas untuk menganalisis wilayah kerja LAGZIS kota Malang, tujuannya, kelembagaannya, sistem pembayaran pajak dikaitkan dengan pembayaran zakat, sistem pengawasannya, dan tenggang waktu penyesuaian organisasi pengelola zakat dengan UU zakat. Bab-bab dan pasal-pasal yang dipakai untuk menganalisis antara lain adalah bab I pasal 1 ayat (1), bab II pasal 5 ayat (1), (2), dan (3), bab III pasal 7 ayat (1), bab IV pasal 14 ayat (3), bab VI pasal 20, dan bab IX pasal 24 ayat (2), berikut penjelasannya, dan KMA nomor 581 tahun 1999 yang terkait dengan bab-bab dan pasal-pasal di atas. Bunyi pasal-pasal tersebut secara lengkap sebagaimana pada lampiran 12 .

Teori tentang zakat untuk menganalisis kelembagaan amil zakat, yaitu LAGZIS kota Malang itu sendiri sebagai obyek penelitian, dan beberapa kebijaksanaannya yang berkaitan dengan penetapan misi dan tujuan lembaga, konsep zakat, infaq dan shadaqah, sumber dana zis, terutama tentang sumber dana zakat, prinsip-prinsip sumber dana zakat, jenis-jenis harta wajib zakat dan kadar (nishab) zakatnya, pendayagunaan zis dan arah penyalurannya. Teori zakat tersebut mengacu pada konsep ayat-ayat al-Qur'an dan hadis Nabi saw. yang berkaitan dengan obyek pembahasan, dan untuk mempertajam analisis penulis juga menggunakan karya alQardhawi dalam Fiqh Zakatnya, dan beberapa pendapat para ulama serta para ahli yang berkaitan dengan tema bahasan. 


\section{Metode Penelitian}

Menyesuaikan dengan persoalan yang diajukan, penelitian ini menggunakan pendekatan studi kasus, yaitu pendekatan yang lebih menekankan pada keutuhan dan kedalaman subyek yang diteliti. Penggalian data dilakukan melalui observasi partisipatif dan wawancara mendalam serta mencermati dokumentasi yang ada, agar peneliti dapat memahami keseluruhan seluk beluk pertumbuhan, perkembangan, bahkan rancangan kelembagaan pada masa yang akan datang.

Atas dasar pendekatan itu, maka langkah-langkah yang dilakukan adalah sebagai berikut: Pertama, melakukan observasi untuk memperhatikan kegiatan yang dilakukan oleh segenap personalia pengelola di LAGZIS kota Malang, mulai dari Direktur ekskutif sampai karyawan tingkat bawa. Kedua, melakukan wawancara berkenaan dengan model dan mekanisme kerja, baik yang berkaitan dengan perencanaan, pengorganisasian, pelaksanaan, dan pengawasan dalam pengelolaan dana zis. Ketiga, mengkompromikan hasil kesimpulan atau temuan dari observasi dengan hasil wawancara dan temuan-temuan dari hasil kajian dokumentasi yang ada, kemudian dianalisis dengan landasan teori, sebagaimana diuraikan di atas.

Proses itu, tentu tidak berjalan linier, melainkan dilakukan secara berulangulang. Oleh karena itu, antara kegiatan penggalian data dan kegiatan analisisnya dilakukan secara simultan dan juga berulang sampai ditemukan pemahaman yang mendalam dan mantap.

Penelitian ini dilakakukan di LAGZIS kota Malang, yaitu lembaga amil zakat yang didirikan pada tahun 1999. Penentuan subyek penelitian tersebut didasari pertimbangan bahwa lembaga tersebut walaupun dari sisi umur masih relatif baru, namun dianggap sangat representatif dan memiliki kredibelitas serta profesionalitas dalam pengelolaan dana zis, khususnya di kota Malang.

\section{Hasil Penelitian}

Dari hasil penelitian yang dilakukan dapat diketahui, bahwa sebagai lembaga amil zakat, LAGZIS kota Malang ini telah memenuhi persyaratan formal sebagai lembaga amil zakat, infaq, dan shadaqah dengan memiliki badan hukum tersendiri, 
namun lembaga ini secara resmi belum dikukuhkan oleh pemerintah, sebagaimana diamanahkan dalam Undang-Undang nomor 38 tahun 1999 tentang Pengelolaan Zakat.

Walaupun demikian, sebagai lembaga pengelola dana zis, lembaga ini telah merepresentasikan diri sebagai lembaga amil yang bersifat modern dan profesional yang memakai prinsip-prinsip manajemen amanah dengan misi dakwah Islamiyah, karena pola dan mekanisme kerjanya berdasarkan pada aspek-aspek manajemen, yaitu aspek perencanaan, aspek pengorganisasian, aspek pelaksanaan, dan aspek pengawasan. Disamping itu, lembaga juga memperhatikan nilai-nilai ajaran yang berkaitan dengan zakat, infaq, dan shadaqah, serta aturan perundang-undang yang berlaku, seperti Undang-Undang nomor 38 tahun 1999 tentang Pengelolaan Zakat dan segala bentuk pertauran perundangan lainnya yang terkait erat dengan pengelolaan zakat.

Jika diperhatikan dari keempat aspek manajemen tersebut, baik aspek perencanaannya, aspek pengorganisasiannya, aspek pelaksanaannya, maupun aspek pengawasannya yang diaplikasikan LAGZIS kota Malang dalam pengelolaan danazis relatif baik dan sesuai dengan ketentuan yang berlaku.

\section{Kesimpulan dan Saran}

\section{A. Kesimpulan}

Dari pembahasan sebagaimana yang diuraikan dalam bab-bab sebelumnya, dapatlah ditarik kesimpulan sebagai berikut :

1. zakat, infaq, dan shadaqah, selain merupakan amalan ibadah wajib dan/ atau sunnah, juga merupakan manifestasi dari tingkat keimanan, keberagamaan, dan kepedulian sosial seseorang, karena pada dasarnya ketiganya menupakan ibadah maliyah ijtima'iyah, yakni ibadah yang berkaitan dengan ekonomi dan kemasyarakatan. Artinya, disamping ketiganya sebagai ibadah mahdhah, juga terkandung di dalamnya kewajiban sosial bagi umat Islam, untuk saling membantu dan saling tolong menolong antar sesama manusia.

Ulul Albab, Vol. 4 No. 1, 2002 
2. Pengelolaan dana zakat, infaq dan shadaqah yang optimal dan profesional merupakan potensi ekonomik yang dapat menjamin atau setidak-tidaknya dapat memberikan konstribusi dalam rangka membangun pertumbuhan ekonomi, sekaligus pemerataan income economis growth with equity.

3. Sistem pengelolaan dana zakat, infaq dan shadaqah oleh Lembaga Zakat, Infaq dan shadaqah (LAGZIS) kota Malang bersifat modern dan profesional yang memakai prinsip managemen amanah dengan misi dakwah Islamiyah, karena pola dan mekanisme kerjanya mengacu pada empat kerangka dasar managemen, yaitu aspek perencanaan, aspek pengorganisasian, aspek pelaksanaan, dan aspek pengendalian atau pengawasan, disamping memperhatikan nilai-nilai ajaran yang berkaitan dengan zakat, infaq, dan shadaqah, serta aturan perundangan yang berlaku, yaitu Undang-Undang nomor 38 tahun 1999 tentang Pengelolaan Zakat.

4. Dari aspek perencanaan; sebagai lembaga profesional LAGZIS kota Malang telah memiliki perencanaan yang baik, yaitu pertama; perencanaan strategis kelembagaan yang didasari dengan pertimbangan yang matang, kedua; perencanaan penentuan visi dan misi lembaga, yang sesuai dengan teori managemen, teori zakat, dan aturan perundangan yang berlaku, yaitu Undang-Undang nomor 38 tahun 1999 tentang Pengelolaan Zakat, ketiga; perencanaan penentuan tujuan, baik tujuan strategis atau tujuan umum, maupun tujuan taktis atau tujuan khusus. Tujuan strategis atau tujuan umumnya adalah menghidupkan baitul mal, mendukung dan mensosialisasikan undang-undang nomor 38 tahun 1999 tentang Pengelolaan Zakat, dan ingin menjadi pengelola dana zis yang profesional. Jika dilihat tujuan yang kedua, LAGZIS kota Malang belum konsisten, karena ternyata lembaganya masih belum mendapatkan pengukuhan dari yang berwenang sebagaimana diatur dalam undang-undang tersebut. Untuk tujuan taktisnya merupakan kebijakan yang diambil sebagai dasar kerja dan pengelolaan dana zis, yaitu kebijakan tentang konsep zis, sumber atau obyek zakat, dan sasaran serta arah pendistribusiannya.

5. Dari aspek pengorganisasian; sebagai lembaga yang profesional LAGZIS kota Malang telah berusaha mengorganisir potensi yang dimilikinya, dengan membuat struktur organisasi dan menempatkan personalia atau orang-orang yang sesuai dengan bidang keahliannya, disertai pembagian tugas yang 
jelas. Disamping itu, lembaga juga memiliki model atau pola pembinaan yang jelas, baik pembinaan untuk para karyawan, untuk para donatur atau muzakki, maupun untuk para mustahiq dengan pendekatan partisipatif dan konsultatif.

6. Dari aspek pelaksanaan; sebagai lembaga yang profesional LAGZIS kota Malang melaksanakan pola kerja yang jelas, baik untuk pelaksanaan penghimpunan dana zis, maupun penyaluran atau pendistribusiannya. Untuk pelaksanaan penghimpunan dana zis, memakai pendekatan personal (door to door/tatap muka/pengajian/presentasi), pendekatan institusional yang bersifat tidak resmi, dan pendekatan kerjasama partisipatif untuk realisasi kegiatan dan penyaluran dana. Sedangkan untuk pelaksanaan penyaluran atau pendistribusian diarahkan untuk peningkatan Sumber Daya Manusia, pengembangan dakwah, dan pengembangan ekonomi. Tiga arah tersebut merupakan klasifikasi yang sengaja dibuat oleh LAGZIS kota Malang berdasarkan teori distribusi menurut al-Qur'an, surat al-Taubah ayat 60 .

7. Dari aspek pengawasan atau pengendalian; sebagai lembaga yang profesional LAGZIS kota Malang menentukan model pengawasan dengan teknik non-kuantitatif, dengan maksud agar masyarakat dapat leluasa melihat, menilai, dan mengkritisi kinerja lembaga. Untuk itu, pada struktur organisasinya tidak tercantum unsur pengawas, karena lebih mengandalkan pada pengawasan publik, melalui media yang dimiliki lembaga. Walaupun pemakaian pengawasan dengan teknik non-kuantitatif tersebut dirasa sangat efektif, terbukti sampai pada waktu penelitian ini dilakukan masih mendapat kepercayaan masyarakat, namun ini tidak sesuai dengan aturan perundangan, yang mengharuskan adanya unsur pengawas dalam struktur kelembagaannya, disamping pengawasan publik atau masyarakat. Sebagaimana disebutkan pada pasal 18 dan 20 undang-undang 38 tahun 1999 tentang Pengelolaan Zakat, jo. Pasal 22 Kepmenag. nomor 581 tahun 1999 tentang Pelaksanaan UU nomor 38 tahun 1999. 


\section{B. Saran-saran}

Untuk meningkatkan sistem pengelolaan dana zakat, infaq dan shadaqah di LAGZIS kota Malang, peneliti memberikan saran-saran sebagai berikut :

1. Untuk meningkatkan hasil pengumpulan dan pendayagunaan zis diperlukan jaringan kerjasama secara melembaga atau institusional dengan tetap mempertahankan pendekatan dialogis dan konsultatif.

2. Perlu membangun hubungan kerja yang sinergis dengan lembaga lain yang sejenis, untuk meningkatkan kemitraan dan mensyiarkan ajaran agama, khususnya tentang zis.

3. Untuk rekrut tenaga/karyawan perlu diperhatikan keahlian/keterampilan yang dimiliki calon, tanpa mengabaikan unsur-unsur lain sebagaimana yang sudah diterapkan oleh lembaga.

4. Sosialisasi tentang keberadaan LAGZIS kota Malang dan programprogramnya harus terus menerus dilakukan, termasuk di lingkungan lembaga/ instansi, baik pemerintah, non pemerintah, perguruan tinggi dan lain sebagainya.

5. Agar keberadaan LAGZIS kota Malang tetap solid dan semakin berkembang serta tidak menemui hambatan, maka pihak pengelola segera mengurus legalitas status kelembagaannya kepada pihak yang berwenang sesuai aturan perundangan yang berlaku.

\section{Endnotes}

1. Kararah, Abbas, al-Din wa al-Zakah, voleme I, al-Maktabah al-Mishriyah, tt. hlm. 276

2. Penegasan ayat al-Qur'an tentang zakat disebut sebanyak 30 kali dan yang terkait dengan kewajiban zakat disebut 28 kali kali.

3. Pengaturan tentang zakat mal dan zakat fitrah tercantum dalam Bijblad No. 1892 tanggal 4 Agustus 1893 dan Bijblad No. 6200 tanggal 28 Pebruari 1905.

4. Yafie, Ali, Teologi Sosial, Telaah Kritis Persoalan Agama dan Kemamusiaan, LKPSM, Yogyakarta, 1997, hlm. 118-119

5. Mahfudh, Sahal, Fiqih Sosial, LKIS, Yogyakarta, 1994, hlm. 145-146

Ulul Albab, Vol. 4 No. 1, 2002 
6. Basyir, Ahmad Azhar, Garis Besar Sistem Ekonomi Islam, Bagian Penerbitan Fakultas Ekonomi Universitas Gajah Mada, Yogyakarta, 1978 hlm. 187

7. Data diperoleh dari Kantor Badan Pusat Statistik Kota Malang pada tanggal 21 April 2002, dan jumlah keluarga tersebut berdasarkan prakiraan untuk masing-masing keluarga berjumlah 4 jiwa.

8. Prediksi tersebut didasarkan perhitungan bahwa wajib zakat dengan stanar emas 85 gram dengan perkiraan harga @Rp. 92.500,- . Jadi zakat tiap wajib zakat =2,5\% X85 X Rp. $92.500,-=R$ p. 196.562,50,-. Kalau jumlah wajib zakat sebanyak 16.841, berarti 16.841 XRp. 196.562,50,-=Rp. 3.310.309.062,50,-

9. Prediksi tersebut didasarkan perhitungan besamya zakat fitrah per wajib zakat sebesar $2,5 \mathrm{~kg}$. beras. Jika diperkirakan wajib zakat yang menunaikan zakatnya sekitar $60 \%$, yalni $60 \%$ X $673.672=404.203$ wajib zakat yang menunaikan zakat fitrahnya, maka hasilnya ; $404.203 \times 2,5 \mathrm{~kg}$. $=1.010 .508 \mathrm{~kg}$. atau 1.010 ton $5 \mathrm{kwintal}$. Jika diuangkan dengan perhitungan harga@Rp. 3.000,-, maka hasilnya ; $1.010 .508 \mathrm{~kg} . X \mathrm{Rp} .3 .000,-=$ Rp. 3.031.524.000,-

10. Mamduh M. Hanafi, Manajemen, Unit penerbit dan percetakan Akademi Manajemen Perusahaan YKPN, Yogyakarta, 1997, hlm. 9

i) Gibson, Jame L., Donnelly, James H. JR., dan Invacevich, John, M., Fundamentals of Management, Penerjemah : Zuhad Ichyaudin, Manajemen, Jilid 1, Erlangga, Jakarta, 1996, hlm. 237

12. Mamduh, Op.Cit. hlm. 9

\section{Bibliography}

Abdullah, Taufik (Ed), Agama Etos Kerja dan Perkembangan Ekonomi, LP3ES, Jakarta, 1970.

Abu Zahrah, Muhammad, Zakat Dalam Perspektif Sosial, Penerjemah : Ali Zaini, PT. Pustaka Firdaus, Jakarta 1995.

Amrullah, Ahmad, AE Priyono dan Bintang Sucipto (Eds.), Islamisasi Ekonomi, PLP2M., Yogyakarta, 1985.

al-Assal, Ahmad Muhammad wa Fathi Ahmad Abdul Karim, Al-Nidham alIqtishad fi al-Islam Mabadiuhu waahdafuhu, Maktabah Wahbah, Kairo, 1977. 
Anwar, Marzani, Pandangan Masyarakat Terhadap Pelaksanaan Zakat, Infaq dan Shadaqah di DKI. Jakarta, Laporan Hasil Penelitian, Kordinasi Dakwah Islam DKI. Jakarta, Jakarta, Desember 1988.

Azra, Azyumardi, Kontroversi Undang-Undang Nomor 38 Tahun 1999 Tentang Pengelolaan Zakat, Laporan Khusus Majalah Ikhlas, nomor 09 Tahun II, 1 Oktober 1999.

Basyir, Ahmad Azhar, Garis Besar Sistem Ekonomi Islam, Bagian Penerbitan Fakultas Ekonomi Universitas Gajah Mada, Yogyakarta, 1978.

dan Ekonomi, cetakan IV, Mizan, Bandung, 1996.

Benda, Harry J., The Crescent And The Rising Sun, Indonesian Islam UndeThe Japanese Occupation 19+2-1945, NV Uitgeverij W van Hoeve, Netherland, 1958.

Buletin Lagzis, nomor 12/Tahun V/1999, Malang, Desember 1999.

Buletin Lagzis, nomor 12/Tahun II/2000, Malang, Desember 2000.

Buletin Lagzis, nomor 1 s.d 12 Tahun III/2001, Malang, Januari s.d Desember 2001.

Daerah Khusus Ibukota (DKI) Jakarta, Rekomendasi dan Pedoman Pelaksanaan Zakat, BAZIS DKI. Jakarta, 1987.

Daerah Khusus Ibukota (DKI) Jakarta, Pedoman Pengelolaan Zakat dan Infaq Shadaqah, Periode Tahun 1984/1985, BAZIS DKI. Jakarta, 1985.

Daud, Ali Muhammad, Sistem Ekonomi Islam, Zakat dan Wakaf, UI. Press, Jakarta, 1988.

—_, Asas-Asas Hukum Islam I, Bulan Bintang, Jakarta, 1983.

Departemen Agama RI., Al-Qur'an dan Terjemahannya, PT. Intermasa, Jakarta, 1986.

—_, Pedoman Zakat Seri I, Proyek Pembinaan Zakat dan Wakaf, Jakarta, 1982.

1982.

Ulul Albab, Vol. 4 No. 1, 2002 
, Pedoman Zakat Seri 3, Proyek Pembinaan Zakat dan Wakaf, Jakarta, 1982.

—, Pedoman Zakat Seri 4, Proyek Pembinaan Zakat dan Wakaf, Jakarta, 1982.

1982.

__ Pedoman Zakat Seri 6, Proyek Pembinaan Zakat dan Wakaf, Jakarta, 1982.

—_, Pedoman Zakat Seri 7, Proyek Pembinaan Zakat dan Wakaf, Jakarta, 1982.

__ Pedoman Zakat Seri 8, Proyek Pembinaan Zakat dan Wakaf, Jakarta, 1982.

-_, Pedoman Zakat Seri 9, Proyek Pembinaan Zakat dan Wakaf, Jakarta, 1982.

_-_._. Partisipasi Masyarakat Dalam Pembangunan Sektor Agama Bidang Zakat (Laporan Penelitian), PUSLITBANG Kehidupan Beragama, Jakarta, 1980/1981.

Donohue, John J. and John L. Esposito (Eds.) Islam dan Pembaharuan, terjemahan Mahmun Husein, Rajawali, Jakarta, 1984.

Fachruddin, Fuad Mohd., Ekonomi Islam, Mutiara, Jakarta, 1982.

Faisal, Sanapiah, Penelitian Kualitatif (Dasar-Dasar dan Aplikasi), Ed. I., Yayasan Asih Asah Asuh, Malang, 1990.

al-Faruqi, Ismail Raji, Tawhid, Its Implication for Thought and Life. The International Institute of Islamic Thought, Washington D.C., 1982.

......, Islamization of Knowledge, International Institute of 1slamic Thought, Washington D.C., 1982.

Gauhar, Altaf (Ed.), The Challenge of Islam, Islamic Council of Europe, London, 1979.

Gibson, Jame L., Donnelly, James H. JR., dan Invacevich, John, M., Fundamentals of Management, Penerjemah : Zuhad Ichyaudin, Manajemen, Jilid 1, Erlangga, Jakarta, 1996. 
, Fundamentals of Management, Penerjemah : Sularso Tjiptowardoyo dan Imam Nurmawan, Manajemen, Jilid 2, Erlangga, Jakarta, 1997.

Harjono, Anwar, Hukum Islam, Keluasan dan Keadilannya, Bulan Bintang, Jakarta, 1969.

Hazairin, Tujuh Serangkai Tentang Hukum, Tintamas, Jakarta, 1974.

—_, Demokrasi Pancasila, Bina Aksara, Jakarta, 1981.

Hornby, A.S., et.al., The Advenced Learners Dictionary of Current English, Oxford University Press, London, 1963.

Ion Hazm, Abu Muhammad Ali bin Ahmad bin Said, Al-Muhalla, V, Maktabah alJumhuriyyat al-Arabiyyan, Mesir, 1968.

al-Jashshash, Abu Bakar Ahmad bin Ali al-Razi, Ahkam al-Qur 'an, Jilid III, Dar al-Kutub al-Arabi, Beirut, t.t.

al-Jaziri, Abdur Rahman, Kitab al-Fiq 'ala al-Madzahib al-Arba'ah, al-Istiqamat, Kairo, t.t.

Kararah, Abbas, al-Din wa al-Zakah, voleme I, al-Maktabah al-Mishriyah, tt. al-Kasani, 'Ala al-Din Abu Bakar bin Mas'ud al-Hanafi, Bada'] al-Shan'l fi Tartib al-Syara'I, Juz Il, Al-Imam, Mesir, t.t.

Keraf, Gorys, Komposisi, Penerbit Nusa Indah, Ende Flores, 1984.

Khurshid, Ahmad, (Ed.), Pesan Islam, Penerjemah : Achsin Mohammad, Pustaka, Bandung, 1983.

Kotb, Sayed, Social Justice in Islam, Octagon Books, New York, 1970.

Mahfudh, Sahal, Fiqih Sosial, LKIS, Yogyakarta, 1994.

Majalah Ikhlas Beramal, Masyarakat dan Bangsa Indonesia memiliki : UndangUndang Tentang Pengelolaan Zakat, Departemen Agama RI., Jakarta, Nomer 09. Th, II, 1 Oktober 1999.

- Kontroversi UU Tentang Pengelolaan Zakat, Departemen Agama RI., Jakarta, Nomer 09 Th. II. 1 Oktober 1999.

Mamduh M. Hanafi, Manajemen, Unit penerbit dan percetakan Akademi Manajemen Perusahaan YKPN, Yogyakarta, 1997

al-Maqsudi, Ibnu Qudamah, Al-Mughni, Jilid II, Al-Manar, Mesir, t.t.

Ulul Albab, Vol. 4 No. 1, 2002 
al-Maududi, Abdul A'la, Dasar-Dasar Ekonomi Dalam Islam dan Berbagai Sistem Masa Kini, Penerjemah : Abdullah Suhaili, PT. Al-Ma'arif, Bandung, 1984.

Moleong, J. Lexy, Metodologi Penelitian Kualitatif, PT. Remaja Rosdakarya, Bandung, 1990.

Mubyarto dan Boediono (Eds.), Ekonomi Pancasila, BPFE Universitas Gajah Mada, Yogyakarta, 1987.

Mubyarto, Ekonomi Pancasila; Gagasan dan Kemungkinannya, LP3ES, Jakarta, 1987.

_- Zakat dan Memerangi Kemiskinan, makalah diajukan pada Seminar Nasional Pengelolaan dan Pendayagunaan Zakat, Infaq dan Amal Jariyah Lainnya, Jakarta, 1-5 Nopember 1982.

Muhammad, Sahri, dan Nuhfil Hanani, Mekanisme Zakat Dalam Kerangka Kebijakan Ekonomi Kesejahteraan, Makalah disampaikan dalam Dialog Refleksi Agama, Politik, dan Kebijakan Ekonomi di STAIN Malang, Program Pasca Sarjana IPB., Bogor, tanggal 12 Desember 1999.

Nasution, Harun, Akal dan Wahyu, UI Press, Jakarta, 1985.

al-Nawawi, Abdul Khaliq, al-Nidham al-Mal fi al-Islam, Maktabatul Anjalu alMishriyah, 1971.

al-Nawawi, Muhyiddin Abu Zakariya Yahya bin Syaraf, Al-Majmu' Syarh alMuhadzdzab, Jilid IV, Al-Imam, Mesir, t.t.

Nazir, Moh., Metode Penelitian, Ghalia Indonesia, Jakarta, 1985.

al-Qardlawi, M. Yusuf, Figh al-Zakat, Jilid I dan II, Dar al-Irsyad, Beirut, 1969.

Penerjemah : Umar Fanani, Bina Ilmu, Surabaya, 1982.

Rahardjo, M. Dawam, Zakat Dalam Perspektif Sosial Ekonomi, Majalah Pesantren, Nomor 2 volume III tahun 1986.

Rais, Amin, Cakrawala Islam, Antara Cita dan Fakta, VII, Mizan, Bandung 1996.

Rida, Sayyed Muhammad, Rasyyid, Tafsir al-Manar, Jilid X, Al-Manar, Mesir, $1353 \mathrm{H}$. 
Sabiq, Sayyid, Fiqh al-Sunnah, Jilid I dan III, Dar al-Bayan, Kuwait, 1968.

Saifuddin, Ahmad Muslih, Nilai-Nilai Sistem Ekonomi Islam, Media Da'wah, Jakarta, 1984.

Sjechul Hadi Permono, Sumber-Sumber Penggalian Zakat, Pustaka Firdaus, Jakarta, 1992.

Swasono, Sri Edi, Al-Muzammil dan Amri Yusra (penyunting), Sekitar Kemiskinan dan Keadilan dari Cendikiawan Kita Tentang Islam, UI. Press, Jakarta, 1987.

__ Pandangan Islam dalam Sistem Ekonomi Indonesia, UI. Press, Jakarta, 1985.

—_ Sistem Ekonpomi Demokrasi Ekonomi, UI. Press, Jakarta, 1985.

- Pedoman Menulis Daflar Pustaka, Catatan Kaki dan lain-Iain, UI. Press, Jakarta, 1985.

al-Syaukani, Nail al-Authar, Jilid IV, Musthafa al-Babi al-Halabi, Mesir, t.t.

Syahhatih, Syauqi Ismail, Penerapan Zakat Dalam Dunia Modern, Penerjemah : Anshari Umar Sitanggal, UI Press, Jakarta, 1987.

Syarifuddin, Amir, Eksistensi Zakat dan Sistem Pendayagunaannya, Makalah diajukan pada Temu Wicara Majelis Ta'lim se DKI. Jakarta, Biro Bina Mental Spiritual DKI Jakarta, Jakarta, 7-16 Nopember 1988.

Ulwan, Abdullah Nashih, Hukum Zakat, terjemahan Bahrun Abubakar, Gema Risalah Press, Bandung, 1988.

Yafie, Ali, Teologi Sosial, Telaah Kritis Persoalan Agama dan Kemanusiaan, LKPSM, Yogyakarta, 1997.

Zainal Abidin, Ahmad, Dasar-Dasar Ekonomi Islam, Bulan Bintang, Jakarta, 1979.

Zainuddin, M., Zakat Dalam Dimensi Sosial; Efektifitas Zakat, Makalah disampaikan pada Seminar Zakat, Yayasan Pena Indonesia, Jakarta, 22-23 Maret 1989.

Zein, Satria Effendi M., Eksistensi Zakat dan Sistem Pendayagunaannya, Makalah disampaikan pada Temu Wicara Majleis Ta'lim se DKI, Biro Bina Mental Spiritual DKI Jakarta, Jakarta, 7-16 Nopember 1988.

Ulul Albab, Vol. 4 No. 1, 2002 
52

Ulul Albab, Vol. 4 No. 1, 2002 